\title{
Sustainability of Accounting Profession at the Age of Fourth Industrial Revolution
}

\author{
Aziza Akhter \\ Lecturer, Notre Dame University Bangladesh \\ Arambag, Motijheel, Dhaka 1000, Bangladesh \\ E-mail: akhteraziza016@gmail.com
}

Reajmin Sultana (Correspondence author)

Faculty of Business Administration, American International University-Bangladesh

408/1, Kuratoli, Dhaka, Bangladesh

Tel: 880-168-224-5144Ｅ-mail: reajmin@gmail.com

Received: September 23, 2018 Accepted: October 20, 2018 Published: October 29, 2018

doi:10.5296/ijafr.v8i4.13689

URL: https://doi.org/10.5296/ijafr.v8i4.13689

\begin{abstract}
According to previous literature and surveys, a technological progression increases the use of technologies in the accounting and auditing profession. Frey and Osborne's (2013) predicted that this profession will face extinction, which leads this paper to study the future prospects of the accounting profession in a global and local context of Bangladesh. At present, technologies are automating routine accounting activities resulting job cut around the world. But the advanced study reveals that technology cannot replace emotional intelligence and critical thinking abilities of a human in near future. As technology is spreading the scope of the profession, knowledge of trending technologies along with some survival skills are required for accountants. This paper tried to present the upcoming trends of the accounting profession, at the same time discusses the required skills to adapt to the technological changes. After observing 18 companies of Bangladesh, it has been found that advanced technologies are not introduced here except software and according to the survey; software's are not affecting accounting employment yet.
\end{abstract}

Keywords: Accounting profession, Automation, Technological trend, Artificial intelligence, Software, Chartered professional accountants, Future of profession 


\section{Mll Macrothink}

International Journal of Accounting and Financial Reporting

ISSN 2162-3082

2018, Vol. 8, No. 4

\section{Introduction}

This thesis studies how the persistent rise of advanced automation in accounting is changing the profession, globally as well as in Bangladesh, and the necessary skills of accountants to survive in the future. At present, human-being and software's are working together in this sector. Advancement in machine learning, artificial intelligence (AI) and robotics are also contributing to the overall development of the accounting profession. Accountants need to be more adaptive and improve their skills to keep pace with machine. Artificial intelligence, robotics, and machine learning are free from human error and have higher processing power; which causes erosion in traditional accounting job. Though, technological platforms are replacing accounting jobs; demand for skilled and high-quality accountants are on the rise. Artificial intelligence helps professionals to learn, think and perform better. A global and practical view of Bangladesh, through this paper, will help to analyze the condition in a better way.

\subsection{Background Study}

The first software package for accountants, VisiCalc, an electronic worksheet, was released in 1978. It reduced the working hours of accountants which let them be more creative. In 1998, QuickBooks Software Company first launched their desktop version. Gradually, technologies are growing to this profession. Frey and Osborne's (2013), gave predictions about probability of automation of some profession:

Table 1

\begin{tabular}{|c|c|c|}
\hline Profession & $\begin{array}{l}\text { Probability of automation } \\
(0-\text { least likely. } 1 \text { - most likely) }\end{array}$ & Level of Risk \\
\hline Human Resources Managers & 0.0055 & Very Low \\
\hline Marketing Managers & 0.014 & Very Low \\
\hline Financial Managers & 0.069 & Low \\
\hline $\begin{array}{lll}\text { Human } & \text { Resources, } & \text { Training, } \\
\text { and } & \text { Labour } & \text { Relations } \\
\text { Specialists, All Other } & \end{array}$ & 0.31 & Low \\
\hline $\begin{array}{ll}\text { Customer } & \text { Service } \\
\text { Representatives } & \end{array}$ & 0.55 & Moderate \\
\hline $\begin{array}{l}\text { Bookkeeping, Accounting and } \\
\text { Auditing Clerks }\end{array}$ & 0.93 & High \\
\hline
\end{tabular}

Tax Examiners and Collectors, 0.93

High and Revenue Agents 


\begin{tabular}{lll} 
Budget Analysts & 0.94 & High \\
\hline Accountants and Auditors & 0.94 & High \\
\hline Payroll and Timekeeping Clerks & 0.97 & Very high \\
\hline Loan Officers & 0.98 & Very high \\
\hline Tellers & 0.98 & Very high \\
\hline Tax Preparers & 0.99 & Very high \\
\hline
\end{tabular}

Source: Frey and Osborne, 2013: 57-72

The technological revolution has numerous effects in accounts and finance job despite its job loss and security problems. The Boston Consulting Group (BCG) in a report in 2015 predicted that one-third of the jobs would be eliminated by smart technologies by 2025 (Note 1) (Sirkin, H., Zinser, M., and Rose, J., 2015). PricewaterhouseCoopers, in 2018 have analyzed task involved in over 20,000 existing jobs across 29 countries to assess the potential risk of automation over next 20 years (Note 2) (Hawksworth, J., Berriman, R. and Goel, S.,2018). Marc Staut, of Boomer Consulting, Inc in 2017 said that artificial intelligence and machine learning will take possession of many of the accounting profession's repetitive work and he also cited a statistics in which tax preparers, bookkeepers, accountants and auditors are among the top professions whose work will be automated (Note 3) (Dominic, 2017). Steve Varley, chairman and managing partner for the UK and Ireland at EY, spoke about how the increased automation has directed the Big Four firm to restructure their hiring practice (Note 4) (Harriet, A., 2016). So automation will lead to job losses for repeating activities like-calculation, reconciliation, and information verification.Bookkeepers, insurance underwriters, tax preparers, accounting professionals, credit analysts and many more professionals will be automated and at the risk of extinction. This study tried to figure out the upcoming technological trend of accounting and changing an aspect of the profession along with the survival guidelines.

\section{Literature Review}

Previous literature ensures that computerization or automation have played a role in changing job responsibilities of the accounting profession. According to (Collier,1984; Carr, 1985; Coopers and Lybrand, 1985; Wilson,1989), from an early stage, accounting profession was associated with computers and subsequent progress in technology have expressively amplified the overall level of computer usage and extended the range of activities which requires computerisation. Wilson \& Sangster (1992) examines the use of computer technology by the UK accounting profession. He conducted an empirical test of computerization amongst a number of different accounting groups, which ensures that use of the computer in accounting is increasing and affecting different areas of this profession. Transaction recording is affected more than audit planning as judgments involve here. 


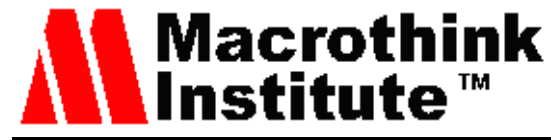

International Journal of Accounting and Financial Reporting ISSN 2162-3082 2018, Vol. 8, No. 4

Technology is replacing low skill jobs. Goldin and Katz (2008) represent a correlation between amplified demand for skills employee with technological progressions and enhanced productivity. According to him, low technical skills generally convert into low-medium skilled jobs which can be easily automated because of their repetitive nature. Bentancourt (n u) examines the impact of technology on public accounting, which shows that in future, more readiness in providing information to clients, an increase of electronics in tax purpose, change the frequency of audit will occur with the adoption of technologies. It helps the accounting to become more complete and efficient. The Association of Chartered Certified Accountants (2013), in a report, have considers the new challenges and opportunities of advanced technology and its impact on the accounting profession. Ramaj (2014) have shown importance acquiring information technology related knowledge in the accounting profession. Through a field survey in Albania, it has been found that the most of the accounting professionals have required knowledge of information technology and it also emphasizes that there is deficiency of knowledge of advanced technology. He also gave some recommendations to increase the knowledge base of accountants. According to Goh, C.; Seow, P.S. and Pan, G. (2017), Employees need to emphasize on strategy and planning work which cannot be easily automated to save their job. To help accountants, organizations need to train them and universities need to ensure that young accountants are equipped with proper technological skills. Tribunella, T. and Tribunella, H. (2005), investigate the differences between practitioner and academic interests in evolving technologies related to accounting. Academics and practitioners have provides a different opinion about the latest technological trend of the accounting profession. Besides skilled graduates, young accountants need to enrich their technological skills. According to ICAEW (2017), Artificial intelligence has widening its scope though it becomes unable to replace the need for expert knowledge and critical thinking ability. Technologies like artificial intelligence help accountants to improve their efficiency by adding new job responsibility which requires critical thinking and intense technological knowledge. The Association of Chartered Certified Accountants in their 'Professional accountants - the future: Drivers of change and future skills' paper, states that "the accountancy profession will evolve significantly over the next decade... all professional accountants will be expected to look beyond the numbers, collaborate, think and behave more strategically" (ACCA, 2016 pg. 21). New technologies require new skills to survive. So, this paper tried to find out the new shape of the profession with trending technologies as well as examining the current situation of Bangladesh.

\section{Research Methodology}

This paper follows qualitative research. Past literature and research findings are used to gather information on a global perspective. Journal articles and websites are also used for collecting information. For conducting research on Bangladesh about automation in the accounting sector, a questioner has been prepared and interviewed. Some information is also collected through telephone conversation.

\subsection{Research Tool}

Interviews have been taken through telephone conversation. 


\section{1l Macrothink}

International Journal of Accounting and Financial Reporting

\subsection{Research Questions}

a. How is accounting job changing for automation?

b. How is the accounting profession affected by technology?

c. What is the situation of the accounting job in Bangladesh?

d. How to survive as an accountant in the world of automation?

\subsection{Sample Size \& Selection}

Sample size is 18 where convenient sampling technique has been used for sample selection.

\subsection{Automation, Artificial Intelligence, Machine Learning and Robotic Process Automation in Accounting}

Automation is a process which follows pre-programmed 'rules' for completing accounting and auditing process. Workflow automation software is used for automating accounting processes like transaction processing, payroll processing, accounts payable, implementing internal control, as well as helps to follow rules regulations, reduces the risk of lost invoices and helps to fraud detection. Paperless invoicing, cloud accounting, automated testing of documents, are examples of automation in accounting. Amazon, Wal-Mart, Nestle, DHL, Adidas are already using automated accounting in their business activities.

Artificial intelligence is the imitation of human intelligence which is processed by computer systems for decision making. It is designed to seek patterns of human thinking, learn from previous experiences and communicate results based on various situations. Learning, Reasoning, self -correction is the main feature of artificial intelligence. Google, Microsoft is working with Artificial Intelligence.

Under robotic process automation, software robots run business process by coping actions of human computer operators. Entering data, copying them among systems with the help of software is done by it. Robotic process automation usually handles rule based repetitive work though Artificial intelligence and Machine learning have the ability to learn with pre-programmed software.

\subsection{Transformation in Accounting Profession Due to Automation}

The gradual changes of accounting profession have been shown below

Table 2

\begin{tabular}{llll}
\hline Activities & Past situation & Present situation & Future situation \\
\hline Data entry & Accountant & Operator/ accountant & $\begin{array}{l}\text { Artificial } \\
\text { intelligence }\end{array}$ \\
\hline Bookkeeping & Accountant & Software & Software/ artificial \\
\hline
\end{tabular}


intelligence

\begin{tabular}{|c|c|c|c|}
\hline Compliance work & $\begin{array}{l}\text { Accountant/ } \\
\text { auditor }\end{array}$ & Software & $\begin{array}{l}\text { Artificial } \\
\text { intelligence }\end{array}$ \\
\hline $\begin{array}{l}\text { Driving to clients to } \\
\text { pick up documents }\end{array}$ & Account's staff & $\begin{array}{l}\text { Electronic documents } \\
\text { passed through e } \\
\text { mail }\end{array}$ & $\begin{array}{l}\text { Electronic } \\
\text { documents passed } \\
\text { through e mail }\end{array}$ \\
\hline $\begin{array}{l}\text { Preparing bills, giving } \\
\text { requisition }\end{array}$ & Accountant & $\begin{array}{l}\text { Software- billing } \\
\text { software, purchase } \\
\text { requisition software }\end{array}$ & Machine learning \\
\hline Preparing ledger & Accountant & spread sheet & Software \\
\hline Receipt reconciliation & $\begin{array}{l}\text { Accountants need } \\
\text { to "balance the } \\
\text { checkbook" }\end{array}$ & software & $\begin{array}{l}\text { machine-readable } \\
\text { data can then } \\
\text { reconcile them }\end{array}$ \\
\hline $\begin{array}{l}\text { Personal investigation } \\
\text { in auditing }\end{array}$ & Auditor & $\begin{array}{l}\text { Use software in } \\
\text { forensic analysis }\end{array}$ & $\begin{array}{l}\text { Artificial } \\
\text { Intelligence }\end{array}$ \\
\hline $\begin{array}{l}\text { Preparing } \\
\text { documents } \\
\text { calculation }\end{array}$ & Accountant & Software & $\begin{array}{l}\text { Machine learning } \\
\text { algorithm }\end{array}$ \\
\hline $\begin{array}{l}\text { Preparing financial } \\
\text { statements }\end{array}$ & Accountant & $\begin{array}{l}\text { Accountants through } \\
\text { help of ERP, SAP } \\
\text { software }\end{array}$ & $\begin{array}{l}\text { XBLR (automated } \\
\text { annual reports) }\end{array}$ \\
\hline
\end{tabular}

\subsection{Global Context: Technological Advancement in Accounting}

Some of the accounting tools used by companies are mentioned below:

- FreshBooks - invoicing for clients

- SageOne - accounting and project management

- Wave - accounting with inexpensive payroll

- Xero - accounting with payroll and accountant friendly tools

- Accounting Power - an accountant-centric system with good payroll

- QuickBooks Online - the major focus of Intuit for accounting

- Net Client CS with ACS and Client Access - Thomson's client accounting system 


\section{Macrothink}

International Journal of Accounting and Financial Reporting

- CYMA - notable payroll and Human Resources management

- Palo Alto Live Planner - a budgeting and planning tool

- Biznet Software - an Excel based reporting tool

- BizTools Professional - a multi-dimensional analytics tool

- Tallie - expense reporting with forms recognition

- Avalara - Sales and Use Tax software to support a SALT practice

- SmartVault - a document management system for QuickBooks

- Bill.com - an Accounts Payable/Accounts Receivable tool that integrates to a number of systems

Source: Johnston, 2016, Tech Issues

\subsection{Current Job Done by Automation}

1. Data processing, analysing and compliance activities are done by software. Portals, e-signature tools, document manager, workflow tools and client server blogs are also being used.

2. Digital checks are used at present. Software is checking images and PDF files and machine learning are automatically tracing customers' accounts.

3. Since 2015, in the Auditing process, KPMG has been using McLaren Applied Technologies (MAT) (Note 5). Machine learning is used to analyse unstructured data. Deloitte-customised is using Kira platform for consulting sector, and more technologies are coming for tax and professional advisory services (Leanor, O.N., 2016).

4. People are using mobile accounting for real time information. Apps are being used to get access to financial data.

5. Financial Process Automation (FPA) is a computerized protected payment and receipt system which has abolished paper invoices, checks and spread excel sheets.

6. Machine learning can identify errors and posts corrective data to the correct account. It can analyse and compare business to another business.

7. Robotic process automation is entering purchase invoices in ERP systems, and opening customer account, inferring applications and other repetitive activities with the help of software.

8. Since July 2013, Securities \& Exchange Commission hosted "RoboCop", an analytical tool which discovers audit failures and securities breaches. PwC is also using RON, a robo-auditor.

9. Cloud accounting, a world class infrastructure facility, provides storing facility, at a low cost without any paper receipt, compliance services and also accessibility from everywhere. 


\section{$\triangle$ Macrothink}

International Journal of Accounting and Financial Reporting

ISSN 2162-3082

2018, Vol. 8, No. 4

For example, QuickBooks, Intuit, Xero, Wave, Zoho, FreshBooks, NetSuite are renowned cloud service provider.

10. Big data aids in assessment of an enormous volume of data, analysis and interpret those data through a sophisticated algorithm. Unstructured data (mail, images, voice, and videos) are being analysed through it for predictive analytics of decision making.

11. Outsourcing reduces cost and helps accountants and business professional to focus on other core activities.

12. Many companies are introducing digital tax accounts, for replacing the annual tax return. In 2013, the instantaneous pay-as-you-earn tax system is introduced which have changed the role of Tax specialist's (Note 6). For identifying data anomalies and reporting an error, analytical tools are attached to this software.

13. Artificial Intelligence tool (Alex, Cartana, and Siri) helps in categorizing and reporting tax line item. Textual analysis, understanding of natural languages, image and voice recognition are used in insurance companies and organizations to detect fraud and surveillance.

\subsection{Future Technologies}

1. Tax agent; tax software will eradicate the use of paper, increase electronic accounting for tax purpose for example, SAT, Mexico. The Computer will substitute human tax agent as well as a need for a physical office.

2. Optical character recognition: OCR turns images into comprehensible text. That means anyone can get a hand printed document from a picture without typing.

3. Auditing practice: Accounting in the cloud will allow executing an audit regardless of the location of same. The rise in Enterprise Resource Processing (ERP) software will support to access whole company data bases for auditing purposes (Note 7).From narrow mechanical process, auditing will move to a more analytical one through this. Artificial intelligence will work with total population instead of a sample which will change the frequency of audit and increase materiality.

4. Cloud technology- Small and medium organization will be dependent on cloud technology in a large number, which will create more accessibility and increase the frequency of transactions.

5. Blockchain: Blockchain is a digital ledger or decentralized database that record data with ample history of the user and the addressee which is impossible to hack. It eliminates the need for auditors to check the accuracy. Some accountants think it will revolutionize the audit industry.

6. Outsourcing will play a great role in future as it has cost minimization effect

7. Barcode system: barcode system accounting will also eliminate checkbox, paper receipts and paper invoices. 


\section{$\triangle 1$ Macrothink}

International Journal of Accounting and Financial Reporting

ISSN 2162-3082

2018, Vol. 8, No. 4

8. Robo advice scene (like Siri), Automated business advice will lead the profession. Chat bot will replace the role of advisor.

9. Databank of advice: technological solution with advice will be available as a package.

10. Internet of things (IoT): IoT will provide more real time data with the interconnectivity of various remote devices.

11. Machine learning: Machine will learn to automatically and quickly answer of Analytics calculation

12. Auditing of expense submissions: Preparing a company's expenses, scrutinizing receipts and auditing expense claims will be done by robotic process automation (Note 8).

13. Clear invoice payments: Xero have introduced a machine learning systems which will classify due invoices, match paid out invoices with payments, clear short payments and produce invoices without human help (Note 9).

14. Risk assessment: with the help of big data, machine learning will assess the risk of big projects. This very comprehensive assessment would be impossible for humans to do in a limited time.

15. Bank reconciliation: Machines will automate bank reconciliations in near future.

\subsection{The Changing Role of the Chartered Professional Accountants}

The role of Chartered Financial Accountants (CPA) has changed over time and will continue to change in the future. It has been transformed from data entry to data analysis and consultative services. Accountants or CPAs requires improving technological knowledge to work with software's, artificial intelligence etc. Furthermore, they have to be aware of cyber security breaches.

Reporting structure has been changed as Xero and Intuit are providing real time information which helps to take prompt decisions. The Robot will take the reporting responsibility in the future.

At present financial accountants need to work with an enormous data from both structured or unstructured sources (for example- audio, video, text etc.) and which necessitate more progressive data analytic skills for that.

The role of management accountants has shifted intensely from transaction processing to business analytics. They must know about cyber security because the cloud cannot give proper security to sensitive data. Management accountants with the help of big data can adapt comprehensive monitoring and control over their accounting information system.

It has become expedient for the Auditors to inspect business transactions and to detect fraud with the help of software with higher accuracy. Database to database verification and automatic audit ratification are new terms to embrace in auditing practice. Need to develop accounting and finance professional's skill data science and cognitive computing. 


\section{Mll Macrothink}

International Journal of Accounting and Financial Reporting

ISSN 2162-3082

2018, Vol. 8, No. 4

\subsection{Threats of Automation}

In 2016, Wal-Mart has laid off 7,000 employees dealing with management cash flows and the processing of vendor claims. As most of the repetitive activities are being automated with accounting software (Xero and QuickBooks) (Note 10).

Cyber security breaches are one of the most alarming threats of highly automated financial sectors.

\subsection{Bangladesh Context: Scope of Accounting Profession in Bangladesh}

Accounting services are previously compared to bookkeeping only but nowadays the term accounting has been changed as Accounting \& Information systems. A new area of accounting service is reporting through which information is delivered to users.

The profession of accountancy evolved during the British colonial period. Today it is managed by two professional bodies, the Institute of Cost \& Management Accountants of Bangladesh (ICMAB) and the Institute of Chartered Accountants of Bangladesh (ICAB).

Table 3

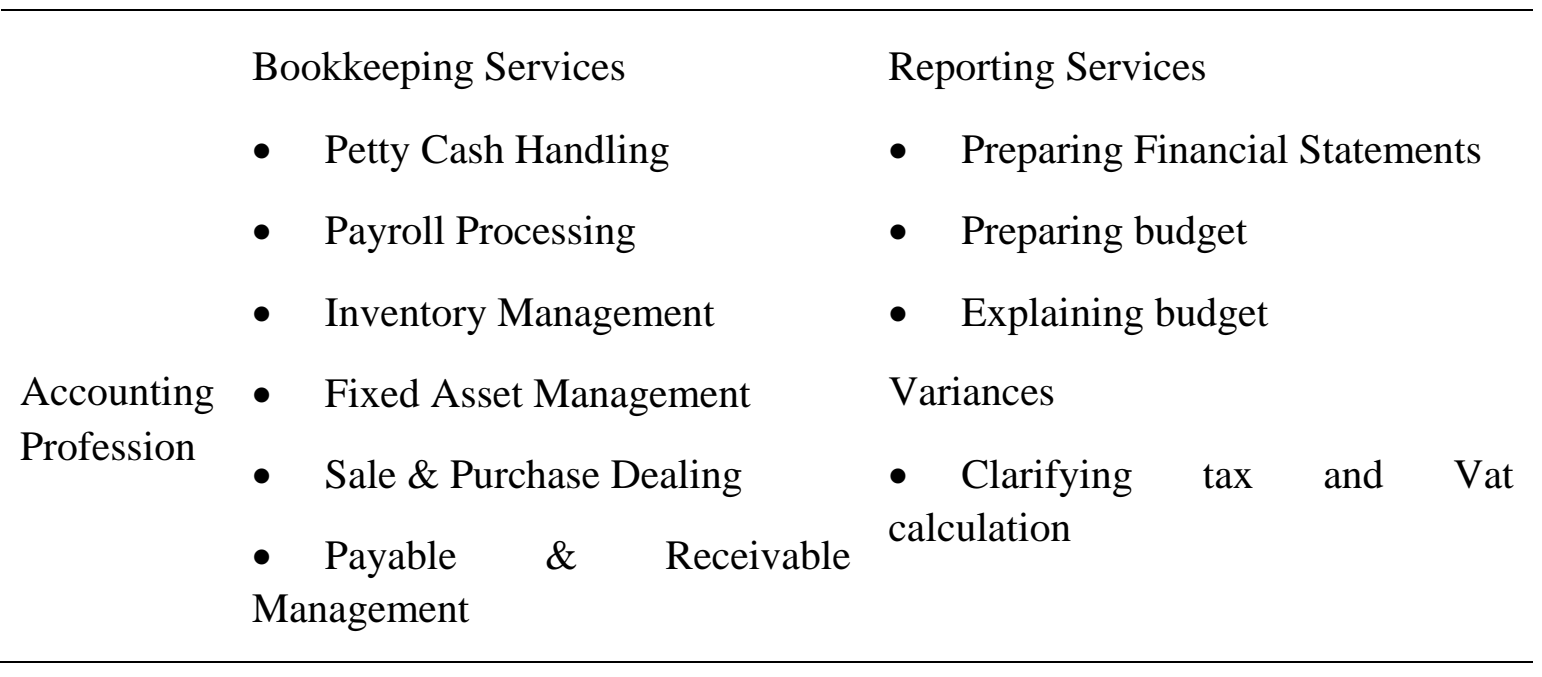

\subsection{Use of Accounting Software in Bangladesh}

At this age of technology doing accounting work becomes very easier with the use of accounting software. From the survey of Bangladesh association of software and information services on accounting software in Bangladesh; it has been found that $47 \%$ of IT industry constitutes use of accounting software.

Here is the chart of some popular accounting soft wares used by following Bangladeshi companies. 
Table 4

\begin{tabular}{|c|c|c|c|}
\hline $\begin{array}{l}\text { SAP } \\
\text { Applications } \quad \text { and } \\
\text { Products) } \\
\text { - ACI Logistics } \\
\text { - Bangladesh Bank } \\
\text { - Bashunbdhara } \\
\text { Group } \\
\text { - British American } \\
\text { Tobacco Paints } \\
\text { - Berger } \\
\text { Bangladesh Limited } \\
\text { - Butterfly- } \quad \text { LG } \\
\text { Bangladesh } \\
\text { - Nestle Bangladesh } \\
\text { - ROBI } \\
\text { - Samsung } \\
\text { - Unilever } \\
\text { - Square }\end{array}$ & $\begin{array}{l}\text { Tally } \\
\text { - Bangladesh } \\
\text { International Airlines } \\
\text { LTD } \\
\text { - University } \\
\text { Dental College \& } \\
\text { Hospital } \\
\text { - BGMEA } \\
\text { - BKMEA } \\
\text { - Alcon } \\
\text { Pharmaceuticals LTD } \\
\text { - Landmark Group } \\
\text { - Amirati } \\
\text { Developments LTD } \\
\text { - Newport Express } \\
\text { (BD) LTD } \\
\text { - Dhaka Shanghai } \\
\text { Ceramics LTD }\end{array}$ & $\begin{array}{l}\text { Quick book } \\
\text { - The Asia } \\
\text { Foundation } \\
\text { Bangladesh } \\
\text { - Transtech } \\
\text { - Euro Bangla } \\
\text { Glass LTD } \\
\text { - Amigo } \\
\text { Properties } \\
\text { Developments LTD } \\
\text { - Desh Television } \\
\text { LTD }\end{array}$ & $\begin{array}{l}\text { Troyee } \\
\text { - } \quad \text { Gazi Group } \\
\text { - } \quad \text { Partex } \\
\text { Group } \\
\text { - } \quad \text { Rangs } \\
\text { Group } \\
\text { - Paradise } \\
\text { Group } \\
\text { - GNet BD }\end{array}$ \\
\hline
\end{tabular}

\subsection{Effect of Accounting Software on Accounting Manpower}

Expansion of accounting software is easily visible here but a challenge is determining the effect of such expansion on accounting manpower. Accounting manpower, we mean no of people engaging in providing accounting services in an organization. Naturally accounting manpower requires accounting educational background. But the use of accounting software may reduce the necessity of accounting manpower with accounting educational background due to its computerized program system.

For determination the effect of accounting software in accounting manpower we have conducted a survey of 18 companies of Bangladesh. The result of which is given below: 


\section{I Macrothink}

International Journal of Accounting and Financial Reporting

ISSN 2162-3082

2018, Vol. 8, No. 4

Table 5

\begin{tabular}{|c|c|c|c|}
\hline $\begin{array}{l}\text { Name of the } \\
\text { Company }\end{array}$ & $\begin{array}{l}\text { Use of Accounting Software } \\
\text { Question } 1\end{array}$ & $\begin{array}{l}\text { Accounts } \\
\text { Accounting } \\
\text { Background } \\
\text { Question } 2\end{array}$ & $\begin{array}{l}\text { Team with } \\
\text { Educational }\end{array}$ \\
\hline Mc Group & 9 & 9 & \\
\hline Talha Fabric Ltd & 9 & 9 & \\
\hline Noman Fabric Ltd & 9 & 9 & \\
\hline Texture BD & 9 & 0 & \\
\hline Goldstar Group & 9 & 9 & \\
\hline Hamid Group & 9 & 9 & \\
\hline Windy Group & 9 & 9 & \\
\hline JS Knitting Group & 9 & 9 & \\
\hline Square & 9 & 9 & \\
\hline AR Group & 9 & 9 & \\
\hline Rim Dyeing Ltd & 9 & 9 & \\
\hline $\begin{array}{l}\text { Unique Washing and } \\
\text { Dyeing Ltd }\end{array}$ & 9 & 9 & \\
\hline Echo Tex Ltd & 9 & 9 & \\
\hline $\begin{array}{l}\text { Far east Knitting and } \\
\text { Dyeing Ltd }\end{array}$ & 9 & 9 & \\
\hline Stitch Right Ltd & 9 & 9 & \\
\hline Grameenphone & 9 & 9 & \\
\hline Robi Axiata & 9 & 9 & \\
\hline Banglalink & 9 & 9 & \\
\hline
\end{tabular}


Question 1: (9 = company using accounting software; $0=$ company not using accounting software)

Question 2: $(9=$ all members of the accounts team has accounting educational background; 0 $=$ all members of the accounts team do not have accounting educational background)

From the above survey, we can conclude that in the accounting field use of accounting software has become a common phenomenon. Out of 18 companies, only one company does not have accounts team with accounting educational background. It indicates expansion of accounting software does not have any effect on accounting manpower. In Bangladesh, accounting systems are not technology oriented rather depended on accounting manpower.

\section{Findings}

\subsection{Technology Is Not a Threat}

In Accounting and finance Function Report, Half (2017), stated that 62 percent of large companies accounting and finance teams are however undermanned, also mentioned having difficulties in finding skillful talent in the hiring process (Note 11). Accounting jobs are growing throughout the centuries and decades as accounting firms are growing by size and responsibilities. There is a deficiency of skilled accountants as more firms are contributing to growing world economy. In existing accounting and finance job market, unemployment rates are low, and companies are in need of an expert. This situation is puffed up with an insufficient supply of skilled accountants and experienced analysts. Technology cannot take the place of emotional intelligence as humans need to be involved in crucial decision making which could not be made by robo-advisor or Artificial intelligence. Advanced technologies are being used in accounting for giving the more exact; real-time data to the clients.so, Accountants need to be updated about technological improvement to adopt the changing requirements.

App developer, cloud computing services, social media manager, and data analysis is the new job area developed by technologies. Artificial Intelligence is performing tasks without human interference and machines are learning to make a decision and communicate to the customer yet, technology is creating more opportunities to work by spreading the area of job responsibilities. The expanded scope of the profession requires analytical skill in financial stalemates.

In Bangladesh, Accounting software is used and it has no impact on accounting unemployment.

\subsection{New Opportunities}

Power of data analytics helps professional accounting firms in spreading advisory service. It also helps to analyse customer's behaviour and advice businesses on the competitive market. Institute of Singapore Chartered Accountants (ISCA) and the Institute of Chartered Accountants in England and Wales (ICAEW, 2016) on "The Future of Professional Learning and Entrepreneurship" report, endured a conversations with a range of professionals, there was common agreement that the real value of the accounting profession lies in the integrity 
and ethics of its members (Note 12). Some of the participants in that conversation pointed out that clients would rather have more trust in audit opinions issued by a human auditor than a robot. Even to run software's there are also need human intervention. ISCA has stressed the need for professional accountants to be the strategic business advisors for the companies for which they work. Asian counties require plenty of skilled accountants for the developed economy of future days. Singapore, Malaysia expressed their need for professional and skilled accountants alongside with their advanced technology. Accountants will get more time for judgemental, creative analysis and financial advisory activities as workloads are reduced for technologies. Accountants should embrace new changes in a new role.

\section{Recommendations}

Martin Ford, admitted in the conclusion of his book, The Rise of Robots, that 'there is no question that the economy will remain heavily dependent on human labor for the foreseeable future'. (Ford, 2015, p. 263). Businesses in the Asian region will need accountants and finance professionals to support their growth, and most emerging markets are short of these professionals. Artificial Intelligence has reformed the activities of an accountant, transformed accounting. Bernard Marr (2017) an author specializing in business, technology and big data, wrote in an article for Forbes that "it is high time for every accountant to reflect on their job, identify the opportunities machine learning could offer to them, and focus less on the tasks that can be automated and more on those inherently human aspects of their jobs". While speaking at Zeitgeist 2015, a conference held in London, Hawking noted, "Computers will overtake humans with AI at some within the next 100 years. When that happens, we need to make sure the computers have goals aligned with ours." (Hawking, 2015) This profession is changing according to the increasing use of technologies and so the time goes, it will evolve more.

Accountants need to develop some qualities to survive in the long run.

1. Adaptability: Accountants need to develop an ability to take challenging of new responsibilities with added values and flexibility beyond historical job descriptions.

2. Critical thinking ability: they need to focus on critical thinking and decision making rather than data entry.

3. Technological skill: CPAs need to develop technological knowledge to work with data analytics and artificial intelligence

4. Communication skill: Good communication skill along with a close relationship with clients help accountants to attain trust and survive.

5. Judgmental capabilities: Need to develop creative analysis ability along with experience to make professional judgments.

\section{Conclusion}

The accountancy profession grows from data entry to ingenious analysis or judgmental accomplishments. As technologies are widening the scope of this profession, accountants 
need to work hand in hand to survive at the age of the fourth industrial revolution. As this paper shows that, technology will not vanish this profession, rather reshaping with new and challenging responsibilities. Robotics automation and drones will replace some manual accounting job, Artificial intelligence will change the role of CPAs but there is an expectation of increasing demand for skilled accountants. For decision making and analysis, there need intuitions and softer skills which can be possible without humane interventions. Cost and security breaches are the main two barriers to adopting artificial intelligence and robotics.

\section{References}

Accounting-degree.org. (n.d.). How Accounting Has Been Changed Over Time With Technology. Retrieved August 11, 2018, from http://www.accounting-degree.org/technology/ Anthonym. (2017). 5 Developments Changing How Cloud Accounting Works. Accounting Web. Retrieved July 17, 2018, from https://www.accountingweb.com/community/blogs/anthonym/5-developments-changing-how -cloud-accounting-works

Anthonym. (2017). Why Accountants Should Embrace Automated Payments. Accounting Web. Retrieved July 16, 2018, from https://www.accountingweb.com/community/blogs/anthonym/why-accountants-should-embr ace-automated-payments

Association of Chartered Certified Accountants and Institute of Management Accountants. (2013). Accountancy futures academy. Digital Darwinism: thriving in the face of technology change. $\quad$ Retrieved April 20, 2018, from http://www.accaglobal.com/content/dam/acca/global/PDF-technical/other-PDFs/Five-mins-o n-Digital-Darwinism.pdf

Association of Chartered Certified Accountants and Institute of Management Accountants (ACCA). (2016). Professional accountants - the future: Drivers of change and future skills. Retrieved June 8, 2018, from https://www.accaglobal.com/content/dam/members-beta/docs/ea-patf-drivers-of-change-andfuture-skills.pdf

Association of Chartered Certified Accountants. (2013). Technology trends: their impact on the global accountancy profession. Retrieved April 20, 2018, from https://www.accaglobal.com/content/dam/acca/global/PDF-technical/futures/pol-af-ttti.pdf

Bangladesh Association of software and Information Services. (n. d.). Bangladesh Software and IT Service Industry Recent Trends \& Dynamics. Retrieved July 16, 2018, from file:///C:/Users/User/AppData/Local/Temp/Rar\$DIa1564.1948/About_Industry.pdf

Bentancourt, R. R. (n.d.). The impact of technology on the public accounting profession Latin America. $\quad$ Retrieved June 8, 2018, from https://www.mgiworld.com/media/909472/The-impact-of-technology-on-the-public-accounti ng-profession.pdf 


\section{MInstitute ${ }^{\text {Mink }}$}

International Journal of Accounting and Financial Reporting

ISSN 2162-3082

Carr, J. G. (1985). Information Technology and the Accountant. Gower publication.

Carron, A. M. (2015). The Impact of Advanced Automation and the Cloud on Employment. Master's Thesis, University of Dublin.

Chang, L. (2016). Walmart is cutting 7,000 jobs due to automation, and it's not alone. Digital $\begin{array}{lllll}\text { Trends. } & \text { Retrieved } \quad \text { July } & \text { 17, } & \text { from }\end{array}$ https://www.digitaltrends.com/business/walmart-cuts-jobs-for-robots/

Chiew, L. F., \& Yeong, L. H. (2017). Will Robots Replace Accountants?. Institute of Singapore Chartered Accountants Journal. Retrieved July 17, 2018, from https://journal.isca.org.sg/2017/07/25/will-robots-replace-accountants/pugpig_index.html

Collier, P. A. (1984). The Impact of Information Technology on the Management Accountant. The Institute of Cost and Management Accountants Occasional Papers Series. United Kingdom.

Coopers \& Lybrand. (1985). The Chartered Accountant in the Information Technology Age. Institute of Chartered Accountants England and Wales. London.

Dominic. (2017). CPAs Should Shift to Niche Services as Automation Takes Over. Accounting Web. Retrieved July 17, 2018, from https://www.accountingweb.com/practice/growth/cpas-should-shift-to-niche-services-as-auto mation-takes-over

Eastwood, G. (2017). How Accountants Can Survive Industry 4.0. Accounting Web. Retrieved July 16, 2018, from https://www.accountingweb.com/community/blogs/garyeastwood/howaccountants-can-surviv e-industry-40

Fineberg, S. (2017). Pathfinder Series Part 2 - A Review. Accounting Web. Retrieved July 16, 2018, from https://www.accountingweb.com/practice/practice-excellence/pathfinder-series-part-2-a-revie W

Flatworld Solutions. (2018). Flatworld Solutions corporate website. Retrieved July 17, 2018, from https://www.flatworldsolutions.com/financial-services/articles/top-5-trends-in-accounting.ph $\mathrm{p}$

Ford, M. (2015). Rise of the robots: technology and the threat of a jobless future. New York. Basic books publications. Retrieved August 2, 2018, from https://www.uc.pt/feuc/citcoimbra/Martin_Ford-Rise_of_the_Robots

Frey, C. B., \& Osborne, M. A. (2013). The Future of Employment: How susceptible are jobs to computerization. Oxford: Oxford Martin School. Retrieved August 4, 2018, from http://www.oxfordmartin.ox.ac.uk/downloads/academic/The_Future_of_Employment.pdf 


\section{MInstitute Macrothink $^{\text {Int }}$}

International Journal of Accounting and Financial Reporting ISSN 2162-3082

Goh, C., Seow, P. S., \& Pan, G. (2017). Automation and the Accounting profession. Institute of Singapore Chartered Accountants Journal. Retrieved from http://ink.library.smu.edu.sg/soa_research/1640

Goldin, C. D., \& Katz, L. F. (2008). The race between education and technology. Cambridge: Mass Belknap Press.

Goodkind, N. (2013). Robots on the Rise: Is Your Job at Risk?. Yahoo Finance. Retrieved July 17, 2018, from http://finance.yahoo.com/blogs/daily-ticker/robots-rise-job-risk-140532110.html

Gottschalk, K. (2017). 5 Things You Need to Know About the Future of Accounting. Accounting Web. Retrieved July 16, 2018, from https://www.accountingweb.com/practice/growth/5-things-you-need-to-know-about-the-futur e-of-accounting

Half, R. (2017). Accounting and Finance Employment Trends. Retrieved July 18, 2018, from https://www.roberthalf.com/accounting-and-finance-employment-trends

Harpar, A. (2018). Technology is the future for accountants but not the risk. Accountancy Age. Retrieved July 6, 2018, from https://www.accountancyage.com/2018/06/14/technology-is-the-future-for-accountants-but-n ot-without-risk/

Harriet, A. (2016, May 9). Technology transforming big four hiring practices. Financial Times. $\quad$ Retrieved August 10, 2018, from https://www.ft.com/content/d5670764-15d2-11e6-b197-a4af20d5575e

Hawking, S. (2015, May). Google Zeitgeist 2015. London. Retrieved May 11, 2018, from https://www.youtube.com/watch?v=IBfwgHLLPfs

Hawksworth, J., Berriman, R., \& Goel, S. (2018). Will robots really steal our jobs? an international analysis of the potential long term impact of automation. Pricewaterhouse Coopers 2018. Retrieved October 6, 2018, from https://www.pwc.co.uk/economic-services/assets/international-impact-of-automation-feb-201

Institute of Chartered Accountants in England and Wales. (2017). Artificial intelligence and the future of accountancy. ICAEW, London. Retrieved October 16, 2018, from https://www.icaew.com/-/media/corporate/files/technical/informationtechnology/technology/ artificial-intelligence-report.ashx?la=en

Institute of Singapore Chartered Accountants (ISCA) and the Institute of Chartered Accountants in England and Wales (ICAEW). (2017). Our Future Together: Industry Perspectives on the Future of Professional Learning and Entrepreneurship. ISCA and ICAEW. Retrieved October 16, 2018, from https://isca.org.sg/tkc/our-future-together/publications/publications/2017/may/industry-perspe ctives-future-of-professional-learning-and-entrepreneurship/ 
Johnston, R. (2016) Tools Are Changing. Tech Issues. Retrieved June 10, 2018, from https://www.tscpa.org/docs/default-source/default-document-library/techissues_janfeb2016.p df?sfvrsn=2

Marr, B. (2017, July). Machine learning, artificial intelligence- and the future of accounting. Forbes. $\quad$ Retrieved April 20, 2018, from https://www.forbes.com/sites/bernardmarr/2017/07/07/machine-learning-artificial-intelligenc e-and-the-future-of-accounting/\#3f13a1432dd1

Nof, S. Y. (2009). Springer Handbook of Automation. Springer. Retrieved July 18, 2018, from https://www.springer.com/gp/book/9783540788300\#aboutBook

Patil, H. (2017). Why Automation will liberate you. Accounting Web. Retrieved July 16, 2018, from

https://www.accountingweb.com/technology/accounting-software/why-automation-will-liber ate-you

Ramaj, B. (2014). Impact of information technology in the accounting profession. 5-th International Conference, Information System and Technology Innovations: "Projecting trends to New Economy". Retrieved June 8, 2018, from https://www.researchgate.net/publication/294890069_Impact_of_information_technology_in _the_accounting_profession

Rezaee, Z., \& Wang, J. (2017). Big data, big impact on accounting. A Plus. Retrieved July 17, 2018, from http://app1.hkicpa.org.hk/APLUS/2017/10/pdf/42,43,45_large\%20source.pdf

Richins, G., Stapleton, A., Stratopoulos T. C., \& Wong, C. (2017). Big Data Analytics: Opportunity or Threat for the Accounting Profession?. Journal of Information Systems, 31(3), Fall, 63-79.

Sirkin, H., Zinser, M., \& Rose, R. (2015, September 23). The Robotics Revolution: The Next Great Leap in Manufacturing. BCG publications. Retrieved June 16, 2018, from https://www.bcg.com/publications/2015/lean-manufacturing-innovation-robotics-revolution-n ext-great-leap-manufacturing.aspx

Smith, A., \& Anderson, J. (2014). AI, Robotics, and the Future of Jobs. Pew Research Center. Retrieved July 17, 2018, from http://www.pewinternet.org/2014/08/06/future-of-jobs/

Tribunella, T., \& Tribunella, H. (2005). Emerging Technologies and the Future of the Accounting Profession. Northeast Region American Accounting Association Meeting. $\begin{array}{llll}\text { Retrieved July } & 17, & \text { from }\end{array}$ http://scholarworks.rit.edu/cgi/viewcontent.cgi?article=1564\&context=article

Wilson, R. A. (1989, December). Accounting systems in industry and public practice. The Accountants Magazine.

Wilson, R. A., \& Sangster, A. (1992). The automation of accounting practice. Journal of Information Technology, 7, 65-75. Retrieved from https://www.researchgate.net/publication/31936878_The_automation_of_accounting_practic e 


\section{MlMacrothink}

International Journal of Accounting and Financial Reporting

ISSN 2162-3082

2018, Vol. 8, No. 4

\section{Notes}

Note 1. Sirkin, H., Zinser, M., \& Rose, J. (2015, September 23). The Robotics Revolution: The Next Great Leap in Manufacturing By https://www.bcg.com/publications/2015/lean-manufacturing-innovation-robotics-revolution-n ext-great-leap-manufacturing.aspx

Note 2. Hawksworth, J., Berriman, R., \& Goel, S. (2018). Will robots really steal our jobs? an international analysis of the potential long term impact of automation. PricewaterhouseCoopers 2018, 1-43.

Note 3. Dominic. (2017). CPAs Should Shift to Niche Services as Automation Takes Over. Accounting Web. Retrieved July 17, 2018, from https://www.accountingweb.com/practice/growth/cpas-should-shift-to-niche-services-as-auto mation-takes-over

Note 4. Harriet , A. (2016, May 9). Financial times Technology transforming big four hiring practices. $\quad$ Retrieved

from https://www.ft.com/content/d5670764-15d2-11e6-b197-a4af20d5575e

Note 5. Leanor , O. N. (2016). How is the accountancy and finance world using artificial intelligence? $\quad$ ICAS. Retrieved July 31, 2018, from http://economia.icaew.com/en/news/june-2017/ai-wont-solve-every-accountancy-problem-sa ys-icaew

Note 6. Huber, N. (2015, July 24). Three ways tech is transforming accounting. Retrieved from https://www.icas.com/ca-today-news/three-ways-technology-is-changing-accounting

Note 7. Bentancourt, R. R. ( $\mathrm{n}$ d). The impact of technology on the public accounting profession Latin America. from https://www.mgiworld.com/media/909472/The-impact-of-technology-on-the-public-accounti ng-profession.pdf

Note 8. Marr, B. (2017, July). Machine learning, artificial intelligence- and the future of accounting. $\quad$ Forbes, Retrieved from https://www.forbes.com/sites/bernardmarr/2017/07/07/machine-learning-artificial-intelligenc e-and-the-future-of-accounting/\#3f13a1432dd1

Note $9 . \quad$ Retrieved from https://www.forbes.com/sites/bernardmarr/2017/07/07/machine-learning-artificial-intelligenc e-and-the-future-of-accounting/\#3f13a1432dd1

Note 10. Chang, L. (2016). Walmart is cutting 7,000 jobs due to automation, and it's not alone. Digital Trends. Retrieved July 17, 2018, from https://www.digitaltrends.com/business/walmart-cuts-jobs-for-robots/

Note 11. Half, R. (2017). Accounting and Finance Employment Trends. Retrieved July 18, 2018, from https://www.roberthalf.com/accounting-and-finance-employment-trends 


\section{Macrothink}

International Journal of Accounting and Financial Reporting ISSN 2162-3082

Note 12. ISCA and ICAEW. (2017). Our Future Together: Industry Perspectives on the Future of Professional Learning and Entrepreneurship, ISCA and ICAEW. Retrieved from https://isca.org.sg/tkc/our-future-together/publications/publications/2017/may/industry-perspe ctives-future-of-professional-learning-and-entrepreneurship/

\section{Copyright Disclaimer}

Copyright for this article is retained by the author(s), with first publication rights granted to the journal.

This is an open-access article distributed under the terms and conditions of the Creative Commons Attribution license (http://creativecommons.org/licenses/by/4.0/) 